\title{
Foreword
}

\section{Regional Integration in Africa}

\author{
Charles Chernor Jalloh \\ Florida International University College of Law, Miami, FL, USA \\ jallohc@gmail.com \\ Ademola Abass \\ Peace and Security Program, United Nations University Comparative Regional \\ Integration Studies, Bruges, Belgium \\ Aabass@cris.unu.edu
}

First, we would like to welcome Professor Ademola Abass, who was invited to be a co-Guest Editor of this Special Issue of African Journal of Legal Studies (AJLS) on the topic of regional integration in Africa. Ademola, who is currently Head of the Regional Peace and Security Program at the United Nations University Institute for Comparative Regional Studies in Belgium, is an expert on peace and security aspects of regional integration.

Second, as stated above, this Special Issue of AJLs focuses on regional integration in Africa. Of course, it is a common reflex to think of regional integration solely in economic terms. This should not be surprising. After all, many international organizations established in Africa and around the world since the end of World War II have aimed at developing economic arrangements to reduce tariff and other non-tariff barriers to trade. Preferential trade areas, free trade areas, customs unions, common markets and economic unions are all key features that today constitute part of the foundational bedrock of the current international trading system centered around the Geneva-based World Trade Organization (WTO). We only need to mention the European Union, the European Free Trade Association, the North American Free Trade Agreement, 
Association of South East Asian Nations Free Trade Area, and the Southern Common Market as some of the more prominent examples of this global phenomenon. And, since 1994, there has been an explosion in regional trade arrangements in different parts of the world with over 575 regional trade agreements notified to the WTO as of July 2013.

Africa also reflects this global trend. Indeed, as we are writing this Foreword, the African Union (AU), which itself is a regional body aimed at eventually achieving economic and political integration, recognizes eight such regional and sub-regional arrangements although many of them have overlapping memberships: Community of Sahel-African States; Common Market for Eastern and Southern Africa, East African Community, Economic Community of Central African States, Economic Community of West African States, Intergovernmental Authority on Development, Southern Africa Development Community, and the Arab Maghreb Union. But, as important as they are, this Special Issue of AJLS does not focus on the economic aspects of regional integration as such. Rather, it proposes to turn the spotlight onto a relatively less discussed subject: the impact and intersection of economic integration processes and initiatives on more political issues especially aspects of human rights and human security. In adopting this approach, we started from the premise that regional integration helps to reduce the risk of conflict in at least two ways.

To begin with, much like the political science literature suggests that democracies do not tend to go to war with each other, it stands to reason that increasing economic and political interdependence among member states to a (sub)regional arrangement raises the potential cost of conflict and may thereby help to dissuade it. Second, regional economic integration facilitates greater cooperation among states on a wide range of security and other more social policy issues. Indeed, issues relating to the free movement of persons, labor and private capital, which are commonly anticipated by regional trade treaties, impliedly suggest that peace and stability are necessary conditions for regional integration. Perhaps this nexus partly explains the panoply of institutional mechanisms that focus on the prevention, management and resolution of conflicts in Africa and that form integral components of the AU's African Peace and Security Architecture.

The first article in this issue, by Vincent Nmehielle, examines three issues: (1) the legality and novelty of the African Union's recent initiative to propose to create a criminal chamber within the African Court of Justice to prosecute international crimes, (2) the question whether the AU's stated plan can be said to be obstructive or distractive, and finally, (3) whether the initiative is necessary when considered against the wider scheme of effective functioning of the 
$\mathrm{AU}$ and its human rights protection regimes. The author concludes that while, the AU's desire to establish an international crimes chamber within its human rights court may have largely been influenced by the politicisation of the international criminal justice system and its concerns about the Icc's nearly exclusive focus on Africa, there is nothing in extant international law that prevents the AU from embarking on such initiative - as some scholars have suggested. However, in his view, it is essential for the AU to conduct a necessity test to assess whether it is practical to create such a tribunal. He maintains that considering the fact that currently 34 African countries have accepted the Rome Statute, which established the ICC, the Africa region should engage with that system in ways that give African members of that multilateral court credible ownership of justice. In this way, they could address atrocity crimes by invoking the complementarity principle and more fruitfully focusing on developing the domestic legal capacity to prosecute such heinous crimes.

On the related topic of the relationship between international prosecutions on the African continent, of the type that has given the AU cause for pause and recently led to proposals by African state parties to the ICC to amend the Rome Statute in addition to crafting the regional court that Nmehielle discusses, Charles Jalloh's contribution examines the complexities surrounding the interplay between the national, regional, and the international. In a paper that constituted his opening remarks at the first ever interactive debate among the ICC's 122 states parties, which was convened in The Hague at the request of the African Union in November 2013, he weighs in on the question of the indictment of sitting heads of state and its consequences for peace, stability and reconciliation in Africa. Jalloh argues that part of the problem with the application of international criminal justice in Africa, which has led to the current tension between the Court and the AU in the Sudan and Kenya Situations, arises partly from the failure of ICC officials and judges to take full advantage of key provisions of the Rome Law. He suggests that the application of carefully negotiated principles in the statute relating to, for example, prosecutorial discretion and complementarity could be more context sensitive and more flexible to address the specific concerns of the fragile post-conflict African states. On the other hand, he argues that while ICC states parties should engage in a deeper dialogue with African countries, it would be difficult for the African members of the ICC to amend substantive statutory provisions such as those relating to non-immunity of sitting government officials from prosecutions. The high level of political support required for such amendments make them unrealistic. A more promising venue might be to negotiate changes to the Rules of Procedure and Evidence of the Court. He proposes that a more open minded discussion of thorny issues between the two sides could help erase the mutual 
suspicion that seems to lead to the current tension in the ICC-Africa relationship. He cites, for instance, the opportunities and challenges presented by the current AU proposal to create a criminal chamber to prosecute international crimes, which Nmehielle discussed in his paper. In this regard, he maintains that it is incumbent upon both the ICC and Africa to consider how their efforts could better complement each other. All the more so given the letter, but also the spirit, of the complementarity principle contained in the Rome Statute.

In the third article contained in this issue, Richard Frimpong Oppong evaluates the expansion of economic integration initiatives in Africa. His paper shows that the various regional and sub-regional arrangements have been accompanied by an increase, if not proliferation, in the number of courts currently operating on the continent. Taking several of those courts - that is, the Courts of Justice of the Economic Community of West African States (ECOWAS), the East African Community (EAC) and the Common Market for Eastern and Southern Africa (COMESA), the Tribunal of the Southern African Development Community Tribunal (SADC) and the African Court of Human and People's Rights - as case studies, Oppong shows that some of these new judicial entities have been especially busy over the past several years. He highlights the diverse subject matter that has come before these tribunals, which are supposed to be focused on issues of economic integration. Yet, he discovers that a wide range of more human rights issues, spanning from the validity of national elections to restrictions on free movement of persons, have effectively began to overtake their dockets. Using the literature on legitimacy, which is known in public international law but much less discussed in the setting of integration courts especially in Africa, he assesses whether such courts can be said to have legitimacy: that is, whether they possess the authority that can be perceived as justified. He claims that the perception that these courts are legitimate is critical to the impact that they would likely have on the regional and sub-regional economic integration processes in Africa. After noting the tension that arises when these courts focus their energies on human rights matters, instead of the economic integration issues that one might typically expect, he sheds light on several difficulties that policy makers must confront. These include the various modes of the appointment, tenure and financial independence of some of the judges who are the actors in these institutions whose decisions could most impact their perceived legitimacy.

In an interesting connection with Oppong's piece, Edefe Ojomo's paper evaluates how the possibility of access to a regional justice mechanism, in the form of the EcowAs Court of Justice, appears to now provide a somewhat viable alternative to less credible sources of national access to justice to those whose rights are infringed upon. She argues that the citizenry of the EcowAS 
states now have an additional jurisdiction that they can invoke to hold their government's accountable. In this view, the choice, despite rules about exhaustion of domestic remedies familiar in international adjudication, is to some extent one between national and sub-regional justice. Somewhat optimistically, Ojomo submits that this seems to imply a new reality where both the national and the regional systems would compete for effectiveness in meeting the justice demands of citizens while also encouraging greater complementarity in their institutional activities.

In the fifth article in this issue, Ademola Abass critically evaluates the African Union's role in the Libyan crisis. The broader context for his analysis is the right of the Union to intervene in member states, if necessary, using military force to avert the commission of mass atrocities. He points out the widespread perception that the AU's response to the 2011 problems in Tripoli was ineffectual. He shows that some believe that the regional body's failure to militarily respond to the Libyan debacle proves, once again, that African countries do not at this stage have the resources or the political will to follow through with their stated right to intervene in member states in defense of innocents. While he suggests that such considerations and the AU's self-evaluation of its performance should factor into any fair assessment of the AU's handling of the Libyan crisis, he contends that most analysts fail to account for the bewildering legal complexities the AU found itself in Libya and in relation to one of its key financers, (late) President Muamar Gaddafi. To Abass, when viewed in the broader context of the relationship between regional intervention initiatives and those at the international level especially the United Nations Security Council and the North Atlantic Treaty Organization (NATO), we get a more nuanced picture of why the AU response failed. It is now up to the interested actors to draw lessons from that experience.

Much like Abass, in the last article of this issue, John Mark Iyi also focuses on NATO's use of force in Libya. He discusses the topic from the perspective of an assessment of the emerging norm of the Responsibility to Protect and the controversies associated with one of its three fundamental pillars: the socalled responsibility to react. He submits that the Libyan crisis confirmed the worst fears of those states which assert that responsibility to protect can be open to abuse. He connects this assertion with recent developments, claiming that it is partly because of the concern with abuse that it has proved difficult for the doctrine to be deployed in the context of the ongoing crisis in Syria. To Iyi, in the African context, for this doctrine to be viable would require bold action from the more powerful countries such as South Africa. He maintains that such a player can creatively use its positioning within other multilateral frameworks and at the United Nations to help achieve the objectives of such goals in Africa. 